\title{
Trade Union Approaches to Global Value Chains: The Indonesian Experience
}

\author{
Reingard Zimmer
}

\begin{abstract}
The evident failure of voluntary corporate codes of conduct and their monitoring has further intensified debates over the purchasing practices and legal accountability of transnational corporations. This article analyses the development of International Framework Agreements as an alternative approach advanced by trade unions and describes the characteristics of these instruments, pointing out their strengths and weaknesses concerning implementation and monitoring. It specifically focuses on the Indonesian Protocol on Freedom of Association, a special framework agreement concluded between Indonesian trade unions and international sportswear firms to protect freedom of association and trade union rights in the Indonesian textile, garment and footwear industries. After presenting the protocol's content, the article discusses findings concerning the implementation and monitoring of the agreement, based on interviews conducted by the author in Indonesia between November 2018 and January 2019. It identifies several key factors that led to the successful promotion of strong trade union rights in the formation phase of the agreement, namely public awareness due to intensive campaigning around a mega sporting event, strong support from different civil society actors and the presence of a neutral facilitator. Overall, the Indonesian Protocol on Freedom of Association is an example of a bottom-up process that strengthens the signatory trade unions and thus serves as a potential model for actors in other countries.
\end{abstract}

Keywords International Framework Agreements (IFAs) · Global Framework Agreements · Implementation of IFAs · Monitoring of IFAs · Indonesian Protocol on Freedom of Association - Global Union Federations · Internationalization of industrial relations

\footnotetext{
R. Zimmer (ه)

Berlin School of Economics and Law, Berlin, Germany

e-mail: reingard.zimmer@hwr-berlin.de

(C) The Author(s) 2021 


\section{Introduction}

Safety deficiencies and labour rights violations in Global South (and Global East) factories at the bottom of global value chains, especially in the textile industry, have been criticised time and again. ${ }^{1}$ This discussion intensified after "catastrophes" like the Ali Enterprises textile factory fire in Karachi, Pakistan, and the Tazreen Fashion factory fire in Bangladesh in 2012. In both cases, hundreds of workers died and many more were injured. ${ }^{2}$ In 2013, the Rana Plaza building near Dhaka, Bangladesh, collapsed, killing more than 1100 workers and injuring many more. In all of these cases, the failure of voluntary codes of conduct and their monitoring instruments became obvious. ${ }^{3}$ These incidents showed that profit interests prevailed over workers' safety.

Consequently, a discussion about transnational companies' legal accountability and their purchasing practices intensified. The trade unions' response was not a legal one, however their general understanding is that decent working conditions are a product of collective bargaining processes, and therefore a question of power. ${ }^{4}$ From the 1990s on, the global union federations (GUFs) have been developing International Framework Agreements (IFAs), which set minimum working conditions standards based on the International Labour Organization's (ILO) core conventions. Global unions negotiate and conclude these IFAs with transnational companies or corporate groups. This article analyses IFAs' development and implementation, in particular with regards to the situation in Indonesia, where a Protocol on Freedom of Association was established.

\footnotetext{
${ }^{1}$ Altvater and Mahnkopf (2002), p. 12; Chossudovsky (2002), p. 23. For an early analysis, see: Fröbel et al. (1979), pp. 21, 75, 115.

${ }^{2}$ Article of Ali Enterprises factory fire: www.ilo.org/global/about-the-ilo/newsroom/news/WCMS 629839/lang\%2D\%2Den/index.htm (last accessed 20 April 2020). In Bangladesh, the Tazreen factory fire caused more than 100 deaths, New York Times 25 November 2012, online: www. nytimes.com/2012/11/26/world/asia/bangladesh-fire-kills-more-than-100-and-injures-many.html? _ $\mathrm{r}=0$ (last accessed 20 April 2020). Many workers died in previous fires in Bangladesh, see: Rubya (2015), pp. 691-692.

${ }^{3}$ Holdcroft (2015), p. 97; Zimmer (2016), p. 2.

${ }^{4}$ Zimmer (2008), p. 158.
} 


\section{International Framework Agreements as a Unique Trade Union Approach}

The International Transport Workers' Federation (ITF) initiated transnational collective bargaining after World War II, long before the discussion about globalisation began. As a reaction to ship owners' flag of convenience (FOC) policy, ${ }^{5}$ the ITF developed a flag of convenience campaign, and started to conclude collective agreements, "which set the wages and working conditions for crews on FOC vessels irrespective of nationality." 6

Facing globalization's negative outcomes, like lower working condition standards, most of the other global union federations began developing their own policies, concluding International Framework Agreements ${ }^{7}$ with transnational companies to ensure adequate working conditions. The United Food, Farm and Hotel Workers Worldwide (IUF) started first, concluding a global agreement already in $1988,{ }^{8}$ from 1995 other GUFs followed. ${ }^{9}$ These IFAs established a minimum standard which has to be regarded in national or regional collective bargaining agreements (CBAs). The process of negotiating an IFA takes about 2 years, and marks the starting point of a long-term relationship between the respective GUF and the transnational company. ${ }^{10}$ IFAs are mostly concluded with one company, and apply to all of that company's locations worldwide, as well as its subsidiaries and suppliers. It is exceptional to cover the whole value chain, as subcontractors are usually excluded. However, discussions about the necessity to take responsibility for the whole value chain have already started.

IFAs developed over time. Early agreements only included ILO Core Labour Standards. Now IFAs contain more specific provisions to protect workers' rights which go beyond the ILO core conventions, including detailed rules on implementation. ${ }^{11}$ Today, there are more than 170 IFAs, which span beyond national boundaries in every sector. ${ }^{12}$ The majority are in the metal and electronics industry,

\footnotetext{
${ }^{5}$ Shipowners started to reflag their vessels after World War II, choosing to register their ships in Global South countries. A flag of convenience vessel is therefore one that flies a different flag than that of the ship's owners.

${ }^{6}$ The FOC campaign is described on ITF's website: www.itfseafarers.org/en/focs/about-the-foccampaign (last accessed 20 April 2021). For further information see: Lillie (2004), p. 47; Zimmer (2020), pp. 178-179. For legal aspects, see: Däubler (1997); Zimmer (2015), p. 103.

${ }^{7}$ Due to the global scope of application, "Global Framework Agreements" (GFAs) may also be used.

${ }^{8}$ This IFA on social standards was concluded with the French food company BSN (Danone), followed by seven other IFAs with Danone on other topics in subsequent years.

${ }^{9}$ Cf. Telljohann et al. (2009), as well as Sobczak (2012), p. 139.

${ }^{10}$ Drouin (2015), p. 222; Thomas (2011), p. 269 (274); Zimmer (2020), p. 182.

${ }^{11}$ More in-depth: Zimmer (2020), p. 181.

${ }^{12}$ Author's list from February 2020.
} 
concluded by IndustriALL. ${ }^{13}$ About $87 \%$ of IFAs are concluded with European transnational companies. ${ }^{14}$ Few agreements cover just one country. But even these can still be characterised as transnational, since they are signed by various actors. For example, the Accord on Fire and Building Safety in Bangladesh (Bangladesh Accord), an agreement on occupational safety and health, is only applicable in Bangladesh, but was concluded by two GUFs on behalf of workers and 196 transnational companies. ${ }^{15}$ Similarly, the Indonesian Protocol on Freedom of Association is limited to Indonesia, but was concluded between Indonesian trade unions and transnational buying companies. These two rather specific agreements may therefore also be characterised as IFAs. ${ }^{16}$

In general, IFAs may be described as a top-down instrument. As a rule, the global unions lead the negotiations, although often European Works Councils or trade unions from (industrialised) countries where parent companies are headquartered, play a central role in negotiations or even lead the process. ${ }^{17}$ Global South trade unions representing producers are seldom included in negotiations, which restrains the implementation of the final agreement.

For example, while it is the case that eight Bangladeshi trade unions ${ }^{18}$ signed the Bangladesh Accord, due to their rather weak position in Bangladesh, ${ }^{19}$ they did not play a major role in negotiations. As usual, GUFs spearheaded the negotiations (in this case, IndustriALL, representing the apparel sector, and UNI Global Union, representing retail), supported by a coalition of NGOs, including the Clean Clothes Campaign. ${ }^{20}$ On the one hand, it is clear that global unions have an understanding of transnational affairs, and by mandate, have to bear the interests of all their member organisations in mind, not just those of a particular region. They also have more resources and are often better trained than trade union officials in the Global South. ${ }^{21}$

\footnotetext{
${ }^{13}$ Including the automobile sector and including suppliers.

${ }^{14}$ Author's list from January 2019. Also see: Telljohann et al. (2009), p. 83; Daugareilh (2006), p. 116; Zimmer (2008), p. 160.

${ }^{15}$ Accord on Fire and Building Safety in Bangladesh: www.bangladeshaccord.org/signatories/ company-signatories (last accessed 20 April 2020).

${ }^{16}$ IFAs may be characterised as follows: a GUF is involved in the IFA's negotiation and conclusion. The agreement is based upon ILO standards, contain a monitoring mechanism, and often include suppliers. Drouin (2015), p. 222 (218); Zimmer (2020), p. 178 (183 f.).

${ }^{17}$ Zimmer (2013a), pp. 317-318; Zimmer (2013b), p. 249.

${ }^{18}$ The Bangladesh Textile und Garments Workers League; Bangladesh Independent Garments Workers Union Federation; Bangladesh Garments, Textile \& Leather Workers Federation; Bangladesh Garment \& Industrial Workers Federation; Bangladesh Revolutionary Garments Workers Federation; National Garments Workers Federation; United Federation of Garments Workers; as well as the IndustriALL Bangladesh Council (IBC).

${ }^{19}$ Rubya (2015), pp. 701-702.

${ }^{20}$ Accord on Fire and Building Safety in Bangladesh, available here: www.bangladeshaccord.org/ signatories (last accessed 20 April 2021).

${ }^{21}$ Concerning power asymmetries between the GUFs and the affiliated union confederations/trade unions, see: Ter Haar and Keune (2014), p. 12.
} 
On the other hand, the less actors directly affected are involved in negotiations, the more difficult implementing the agreement becomes. ${ }^{22}$

GUFs are aware of previous campaigns' limitations and the fact that it might be difficult for individual factories to stay competitive after significant working condition improvements, ${ }^{23}$ making the need for more comprehensive solutions clear. The Bangladesh Accord's binding provisions on factory inspections and trainings is seen as a step towards a more comprehensive approach. ${ }^{24}$ Action, Collaboration, Transformation (ACT), an initiative to promote living wages in the garment industry by IndustriALL and 20 transnational companies, ${ }^{25}$ go a step further. It promotes the idea that living wages "should be reached through collective bargaining between employers and workers and their representatives at industry level."26 Promoting collective bargaining at the industry level is considered an opportunity to overcome the risk of companies' social dumping. ${ }^{27}$ Another example is the Indonesian Protocol on Freedom of Association, which supports Indonesian trade unions in organising textile, garment and footwear workers, and secures the signing trade unions' access to factories to organise campaigns, as detailed below.

\section{Indonesian Freedom of Association Protocol}

The Indonesian Protocol on Freedom of Association, ${ }^{28}$ an agreement to protect freedom of association and trade union rights in Indonesia's textile, garment and footwear industry was signed in June 2011. It was concluded between five Indonesian trade unions, ${ }^{29} 35$ local suppliers and the transnational sportswear brand companies Adidas (Germany), Asics Corp (Japan), New Balance (US), Nike Inc (US), Pentland Group PLC (Great Britain), and Puma SE (Germany). In the beginning of 2017, three further companies (Haglöfs, Kjus and SuitSupply), members of the multi-stakeholder organisation Fair Wear Foundation, joined the agreement. ${ }^{30}$ Its

\footnotetext{
${ }^{22}$ Zimmer (2020), p. 190.

${ }^{23}$ Holdcroft (2015), p. 98.

${ }^{24}$ Holdcroft (2015), p. 99; for more information on the accord, see: Zimmer (2016); Zimmer (2020), p. 197.

${ }^{25}$ Holdcroft (2015), p. 100.

${ }^{26}$ See: ACT initiative: www.actonlivingwages.com/fact-sheet/ (last accessed 20 April 2021).

${ }^{27}$ Holdcroft (2015), p. 101.

${ }^{28}$ This article is partly based upon textual analysis and the author's interviews in Indonesia between November 2018 and January 2019. The author thanks Muthi Muthmainah for her support in this research, and during her stay in Indonesia.

${ }^{29}$ These are: SPN (National Labour Union), KASBI (Indonesian Trade Union Congress), Garteks SBSI (Garment, Textile, Shoe und Leather Union), GSBI (Indonesian Workers' Association), FSPTSK (Association of the Textile, Garment and Leather Trade Unions).

${ }^{30}$ More information is available here: www.fairwear.org/news/fwf-members-sign-indonesian-foaprotocol (last accessed 20 April 2021).
} 
standard operating procedures (SOPs), with provisions on monitoring through a national supervisory committee, were adopted in December $2012 .^{31} \mathrm{Next}$, the agreement and the SOPs' content is presented and analysed, as well as factors that enabled the agreement's conclusion and its implementation in practice.

Freedom of association is formally guaranteed in Indonesia in statutory provisions (Article 28 E No. 3 of the constitution, ${ }^{32}$ supplemented by the Presidential Decree No. 83 of 1998, ${ }^{33}$ and Article 104 para. 1 Law No. 13 of 2003 on Manpower). ${ }^{34}$ As statutory provisions, they have to be interpreted and applied to concrete circumstances in practice. Although freedom of association and trade union rights are formally guaranteed in Indonesia, they are constantly violated in practice. ${ }^{35}$ Therefore, their specification and implementation through social partners ${ }^{36}$ by other means is of vital importance.

\subsection{Content of the Freedom of Association Protocol: Protection of Trade Union Rights}

The signing parties are obliged to respect freedom of association at factory sites (Article 2 para. 1, p. 1 of the protocol). ${ }^{37}$ Upon signing the agreement, brands and suppliers guarantee not to violate trade union rights in Indonesia. Based on Article 4 para. 3, employers guarantee not to interfere in any way with the organisational activities of the trade unions party to the agreement. This provision goes beyond neutrality clauses, which can be found in some IFAs. It entails that the signing trade unions have the right to enter production sites and become registered company trade unions for that factory, and further means that the company cannot prevent any organising campaigns. ${ }^{38}$ This applies to all trade union signatories of the agreement therefore ensures plurality of trade unions and non-discrimination against specific trade unions (Article 4 para. 2).

Furthermore, provisions to support trade unions' work within companies are part of the protocol. For instance, trade union representatives have to be released from

\footnotetext{
${ }^{31}$ The standard operating procedures for the freedom of association protocol supervision and dispute settlement resolution committee.

${ }^{32}$ Article 28 E No. 3 of the Indonesian constitution reads: "Every person shall have the right to the freedom to associate, to assemble and to express opinions".

${ }^{33}$ Presidential Decree No 83 of 1998 on the Ratification of the International Labour Organization Convention No. 87.

${ }^{34}$ Muthmainah (2021), p. 5.

${ }^{35}$ ITUC (2019), p. 10.

${ }^{36}$ The social partners are the organisations representing the workers (trade unions) and capital (employers' organisations).

${ }^{37}$ All following Articles, if not otherwise specified, refer to the Freedom of Association Protocol.

${ }^{38}$ As long as the activities stay within existing law.
} 
their work duties to carry out organisational activities, while the company must respect all rights to which the workers normally are entitled (Article 4 para. 4). ${ }^{39}$ Entitlements for paid leave are relative to the factory's size (Article 4 para. 6). In addition, companies have to provide facilities for trade union meetings (Article 5 para. 1(a)), and union representatives "may make use of communication facilities such as telephones, fax and internet within the company as long as such facilities are available," (Article 5 para. 1(a)). Moreover, trade unions are allowed to place their flag at a prominent place in the factory (Article 5 para. 1 (d)), and have the right to display a union signboard on the premises. In addition, several provisions prohibit discrimination, punishing workers because of their trade union affiliation or related work, and hindering the work of trade unions on the factory premises. These rather specific provisions to facilitate trade union work inside factories are not found in other IFAs, although they are common rights of workers' representatives in industrialized countries.

\subsection{Scope of Application}

The protocol Article 2 Paragraph 1, page 2 only covers first-tier suppliers-transnational brands' main supply firms. ${ }^{40}$ In the "initial phase," subcontractors are outside the scope of application, and rather have to be "informed and encouraged" 41 to adhere to the agreement's provisions. This "initial phase" has lasted already for 10 years, with no end in sight. Nevertheless, around 300,000 workers are covered ${ }^{42}$ as first-tier suppliers' production sites make up a large portion of the overall process.

\subsection{Factors That Promote Strong Trade Union Rights in the Formation Phase}

As the Indonesian protocol contains strong trade union rights and details how to realise them, a central question is: how could such a strong agreement have been achieved?

\footnotetext{
${ }^{39}$ These are further specified in Article 5 and following.

${ }^{40}$ These are suppliers that "produce finished goods for the Brands" (1), "have a direct legal manufacturing contract with the Brands" (2), and "have workplace auditing conducted by the Brand's compliance team" (3), or "have a system whereby all auditing of Codes of Conduct or supplier company workplace standards are conducted by a third-party auditor" (4).

${ }^{41}$ Such wording is used in many IFAs.

${ }^{42}$ Ferenschild (2018), p. 3.
} 


\subsubsection{Public Awareness Due to Intensive Campaigning Around a Mega Sports Event}

The Indonesian Freedom of Association Protocol was reached after an intense period of negotiations that started in 2009. Different to Bangladesh, there was no catastrophe with numerous dead workers. Nevertheless, in 2008, a coalition of global and European trade union confederations and civil society launched a powerful international campaign for the Beijing Olympics, addressing labour rights violations in sporting goods' global value chains in Southeast Asia. Adidas, Nike, Puma and other brands were called on to take responsibility for labour rights violations along their value chains. A report entitled Clearing the hurdles identified central obstacles to overcome: low wages, precarious short-term contract employment, violations of freedom of association, and factory closures due to industry restructuring without compensation pay. ${ }^{43}$ In June 2008, the Play Fair Alliance and Indonesian trade unions met with the main transnational sportswear companies for a 3-day conference in Hong Kong. At this conference, the German company Adidas suggested starting a dialogue on working conditions at the national level in Indonesia and tried to get support from other brands. ${ }^{44}$

\subsubsection{Why the Topic of Freedom of Association?}

Negotiations finally settled on the topic of violations of freedom of association, as extreme "union busting" was a widespread occurrence in Indonesia at the time. ${ }^{45}$ Some interviewees ${ }^{46}$ explained in addition, that the sportswear brands were more open to the topic of freedom of association than to negotiate wage increases, the termination of precarious short-term contracts, or of unpaid leave due to factory closures-all issues that bear a higher cost on companies. ${ }^{47}$ An Adidas representative described his company's motivation, "As there were lots of disputes about trade union rights in Indonesia, an agreement giving concrete guidance (supplementing statutory provisions), was considered as helpful." He frankly admitted that "shareholder interests" were also an important motivation for joining the initiative. If company-level disputes could be prevented, this would be ideal risk-prevention, ${ }^{48}$

\footnotetext{
${ }^{43}$ Maquila Solidarity Network (2008), p. 47.

${ }^{44}$ Ferenschild (2018), p. 3.

${ }^{45}$ Interview with Sharif Arifin (LIPS) and Iwan Kusmawan (SPN), 2 November 2018.

${ }^{46}$ Interviews conducted with representatives of all signing Indonesian trade unions, Adidas, a supplier, and NGO representatives were between November 2018 and January 2019.

${ }^{47}$ Interviews with Emilia Yanti (GBSBI) on 9 November 2018, and Parto Sumarto (KASBI) on 13 November 2018.

${ }^{48}$ Interview with Harry Nurmansyah (Adidas office in Jakarta) 13 November 2018.
} 
an argument of the employer side, which can be detected as the central motivation for the conclusion of IFAs. ${ }^{49}$

The (Indonesian) unions considered freedom of association a starting point, and acted on the assumption that negotiations over the other three issues would follow. The workers' side has been advocating for a second and third protocol regarding "wages" and "job security," drafts have already been written. ${ }^{50}$ Due to employers" reluctance, the conclusion of further agreements is not in sight.

\subsubsection{Strong Support from Different Actors}

International and national civil society actors, such as NGOs and trade unions, as well as Indonesian trade unions, were involved in and supported the Indonesian negotiation process, which begun in 2009. ${ }^{51}$ Oxfam Australia financed the position of a coordinator who facilitated the negotiation process, which the Clean Clothes Campaign took over in 2018. In addition, all actors said consistently, that the Adidas representative played an essential role and took the employer-side lead whenever negotiations stalled. ${ }^{52}$

\subsubsection{A Neutral Facilitator as a Central Factor for Success}

A coordinator supported the negotiation process, facilitating meetings, actively motivating actors, and coordinating behind the scenes. Everyone interviewedthose representing trade unions, as well as employers - saw the coordinator's neutral role an essential element in the process' success. ${ }^{53}$ Nevertheless, the coordinator did not have procedural competences. A stronger coordinator position could have influenced the actors in case of an impasse. It could be beneficial to install someone with broader competences, such as double voting rights, to be even more effective. While the current solution seems to have been more or less effective for this

\footnotetext{
${ }^{49}$ Zimmer (2008), p. 189 with further references.

${ }^{50}$ Interview with Franky Tan (FSPTSK Reformasi) on 28 November 2018, and Emilia Yanti (GBSBI) on 9 November 2018.

${ }^{51}$ These included: Oxfam Australia, Jakarta Legal Aid Institute, LIPS (Sedane Labour Information Institute), TURC (Trade Union Research Institute), and AKATIGA (Pusat Analisis Sosial). British trade unions invited an Indonesian representative for the Play Fair Campaign, and a ITGWLF representative was also involved.

${ }^{52}$ The interviewees could not elaborate the factors leading to that role.

${ }^{53}$ In interviews with: Sharif Arifin (LIPS) on 2 November 2018; Mimmy Kowel (coordinator of decent work working group) on 7 November 2018; Emilia Yanti (GBSBI) on 9 November 2018; Parto Sumarto (KASBI) on 13 November 2018; Chris Wangkay (formerly OXFAM Australia) on 14 November 2018; Elly Silaban (KSBSI/Garteks) on 21 November 2018; Lilis Usman (former SPN, now KSPN) on 23 November 2018; Franky Tan (FSPTSK Reformasi) on 28 N November 2018 and Indrasani Tjangdraningsih (AKATIGA) on 15 December 2018.
} 
negotiation process, according to the interviewees, it has proven rather ineffective in conflict resolution (in the National Committee).

\section{Low Involvement of Global Union Federations}

While global unions were hardly involved in the negotiation process (and still are not) ${ }^{54}$ labour rights NGOs played a major role. It seems that Indonesian trade unions wanted to run their own affairs, and considered strengthening trade union rights in their country an Indonesian concern. ${ }^{55}$ Therefore, they did not maintain the contact with ITGLWF (now IndustriALL), the textile and garment sector GUF. The Indonesian trade unions' focus was on brands fulfilling their promises. ${ }^{56}$ Furthermore, not all Indonesian trade unions are members of the respective GUF. ${ }^{57}$ Most of the Indonesian trade union leaders involved did not seem aware that in the struggle against transnational companies, the workers' side is stronger the more international actors involved put pressure on the companies. Concerning trade union rights, international NGOs are not strong enough actors on their own.

\section{Implementing the Freedom of Association Protocol}

Effective implementation of the protocol's comprehensive provisions remains a concern. Therefore, in the following, I turn to the implementation measures laid forth in the protocol and SOPs, and analyse the provisions' functionality in practice to identify problems and positive aspects.

The Indonesian protocol contains wide-ranging implementation mechanisms. The signing parties committed to supervise the implementation of the agreed provisions (Article 3 para. 7). Even though Adidas integrated information about the Freedom of Association Protocol into its local management training and internal audit procedures, it has never offered specific training on freedom of association. The topic seems to be a rather small part of Adidas' programs. ${ }^{58}$ The interviewed trade union representatives described supplier firms' local management as poorly informed about and trained in the protocol. Capacity building and training trade

\footnotetext{
${ }^{54}$ In the beginning, a representative from the former International Textile Garment and Leatherworkers' Federation (ITGWLF, now part of IndustriALL) was shortly involved, as was a British trade union representative.

${ }^{55}$ Interview with Iwan Kusmawan (SPN) on 2 November 2018; Emilia Yanti (GBSBI) on 9 November 2018; Franky Tan (FSPTSK Reformasi) on 28 November 2018.

${ }^{56}$ Interview with Sharif Arifin (LIPS) on 2 November 2018; Mimmy Kowel on 7 November 2018.

${ }^{57}$ Only SPN and KSBSI/Garteks are affiliated with IndustriALL.

${ }^{58}$ Interview with Harry Nurmansyah (Adidas Indonesia) on 13 November 2018.
} 
unionists at the local factory level seems to vary tremendously between organisations, which indicates that also local trade union activists might not all be well informed about the protocol's content.

Supervision and dispute settlement committees were formed (as agreed in Article 7), both on the national level and in most factories. Factory committees are made up of local management and trade union representatives, but seem to operate rather as monitoring bodies than dispute settlement committees, as no (binding) outcome is foreseen in cases of conflict. ${ }^{59}$ A National Committee-formed of signing parties' representatives - meet frequently or upon request to take key decisions. Under certain conditions, NGOs may be granted observer status in the committee (Article $3.4 \mathrm{SOP}$ ). While the SOPs contain specific provisions pertaining to their operationalisation, the interviewed trade union representatives did not describe the committees as being effective. All interviewees saw a neutral coordinator to facilitate the national committee's meetings as a positive element, ${ }^{60}$ although this chair has no procedural power. So far, the National Committee has not been able to take a decision in cases of conflict. Nevertheless, the trade unions described direct contact with the brands through the national committee as positive.

Although violations of trade union rights in factories bound by the protocol are still reported, all interviewed trade unionists described the Freedom of Association Protocol as a "door-opener" to unionise new factories. ${ }^{61}$ As not all of the Indonesian union federations seem to be engaged in organising campaigns, ${ }^{62}$ and some reported not having any problems with the management at all, ${ }^{63}$ it cannot be evaluated exactly how effective the agreement is in this respect. Nevertheless, all interviewed trade unionists stated that in case of a problem, they would call the sourcing brand representative, which in many past cases would have been successful. The protocol (and national committee's work) enabled this direct line of communication.

The protocol acknowledges trade union plurality and assures that specific trade unions will not be discriminated against (Article 4 para. 2). Therefore, especially the more radical (and participation-oriented) trade unions use the document to enter factory premises where the biggest and rather moderate trade union confederation (SPN) already has a presence. In this respect, trade union representatives of the smaller organizations see the Freedom of Association Protocol as a useful instrument. ${ }^{64}$ Nevertheless, trade union rights in the Indonesian textile, garment and

\footnotetext{
${ }^{59}$ The national monitoring committee may make recommendations that have to be followed. Nevertheless, no such recommendations have ever been made.

${ }^{60}$ Interviews with Iwan Kusmawan on 2 November 2018; Emilia Yanti (GBSBI) on 9 November 2018; Parto Sumarto (KASBI) on 13 November 2018; Elly Silaban (KSBSI/Garteks) on 21 November 2018; Lilis Usman (former SPN, now KSPN) on 23 November 2018; Frank Tan (FSPTSK Reformasi) on 28 November 2018.

${ }^{61}$ Interview with Sharif Arifin (LIPS) on 2 November 2018; Chris Wangkay (formerly OXFAM Australia) on 14 November 2018.

${ }^{62}$ Using organising campaigns to enter new factories was documented only for GSBI.

${ }^{63}$ Interview with Iwan Kusmawan (SPN) on 2 November 2018.

${ }^{64}$ Interview with Emilia Yanti (GBSBI) on 9 November 2018; Parto Sumarto (KASBI) on 13 November 2018.
} 
footwear sector are still violated, as some interviewees explained. ${ }^{65}$ The interviewees' statements remain rather vague about the extent to which the protocol enables participating trade unions to enter completely new (so far unorganised) factories. However, according to the interviewed trade unionists, in quite a number of factories, management provides a room for trade union affairs, as foreseen in the agreement, and organisers may be excused from their work duties. ${ }^{66}$

In addition, the agreement foresees collective bargaining agreements be concluded within 6 months of a union's formation at the factory level (Article 6 para. 1), and requires companies have an open attitude towards CBA negotiations (Article 6 para. 1 (a)). As no specific CBAs were concluded, the protocol does not seem to facilitate collective bargaining processes. Either trade unions conclude CBAs as discussed and defined in their organisations, or they do not engage in collective bargaining and accept the statutory minimum wage.

\section{Conclusions}

The Indonesian Protocol on Freedom of Association is an example of a bottom-up process with local (national) trade unions as the driving force in the negotiations process - a central factor for an International Framework Agreements' successful implementation. Local actors" "ownership," commitment and will to make use of the agreement are greatly important to its success. ${ }^{67}$ As Indonesian trade unions negotiated the protocol, its contrast to most other IFAs (concluded by a global union federation) is evident. Nevertheless, supplier firms' involvement in the negotiation process could have been intensified. The companies' suppliers "had to" sign the protocol, but do not seem to have been involved in discussions about its content or implementation. In practice, supplier firms' local management is the central employer-side actor in practice. Involving them more in the negotiation of the protocol's content would have been helpful for implementation, as it was partly the case in the ACT initiative process. ${ }^{68}$

Implementation measures do not seem to be particularly efficient. The main benefit for Indonesian textile, garment and leather unions seems to be their contact with the brands, which the agreement enables. Moreover, the parties unanimously described the positive aspect of starting a social dialogue at the national level, which

\footnotetext{
${ }^{65}$ Interview with Sharif Arifin (LIPS) on 2 November 2018; Emilia Yanti (GBSBI) on 9 November 2018; Parto Sumarto (KASBI) on 13 November 2018; Andriko Otang (TURC) on 12 November 2018.

${ }^{66}$ Interview with Iwan Kusmawan (SPN) on 2 November 2018; Emilia Yanti (GBSBI) on 9 November 2018; Parto Sumarto (KASBI) on 13 November 2018.

${ }^{67}$ Zimmer (2020), p. 196; Stevis and Fichter (2012), p. 667.

${ }^{68}$ For further information about the ACT initiative: www.actonlivingwages.com/fact-sheet/ (last accessed 20 April 2020).
} 
did not exist in Indonesia before. ${ }^{69}$ In addition, Indonesian trade union confederations' capacity building process started with the signing of the agreement. ${ }^{70}$ Still, implementation measures could be intensified with more trainings, but that depends on foreign financial support. In particular, Indonesian trade unions receive at least partial access to factory premises, which is essential for further trade union work, and more than what is achieved elsewhere.

The following aspects warrant improvement: intensified training of local management and workers' representatives would support the agreed provisions' implementation. The national committee's work could be tremendously enhanced by a chair with more competences than in the current solution, a chair who could influence actors in case of an impasse. It would be even more effective to introduce a real and binding conflict-resolution mechanism. This would not have to be the costly UNCITRAL regulation for international commercial arbitration as chosen for the Bangladesh Accord. ${ }^{71}$ Other solutions such as an online tribunal with internationally recognised labour law experts would be possible and less costly. In addition, more strongly involving the competent global union federation IndustriALL would significantly support the struggle of Indonesian trade unions.

Overall, the Indonesian Freedom of Association Protocol strengthens the signing trade unions, and is therefore an example for actors in other countries.

\section{References}

Altvater E, Mahnkopf B (2002) Globalisierung der Unsicherheit. Arbeit im Schatten, Schmutziges Geld und informelle Politik. Westfälisches Dampfboot, Münster

Chossudovsky M (2002) Global Brutal. Der entfesselte Welthandel, die Armut, der Krieg. Zweitausendeins, Leipzig

Däubler W (1997) Der Kampf um einen weltweiten Tarifvertrag. Nomos, Baden-Baden

Daugareilh I (2006) Les accords cadres internationaux: une réponse européenne à la mondialisation de l'économie. In: Descolognes, Michèle/Saincy, Bernard (Hrsg.), Les nouveaux enjeux de la négociation sociale interntionale, Editions La Découverte, pp 116-129

Drouin RC (2015) Freedom of association in International Framework Agreements. In: Blackett A, Trebilcock A (eds) Research handbook on transnational labour law. Edward Elgar, Cheltenham, pp 217-229

Ferenschild S (2018) Fact Sheet: Nur Papiertiger? Indonesien und Kollektivverhandlungen. Südwind, Bonn

Fröbel F, Heinrichs J, Kreye O (1979) Die Neue internationale Arbeitsteilung. Rowohlt Reinbek, Hamburg

Holdcroft J (2015) Transforming supply chain industrial relations. Int Labour Rev 7:95-104

\footnotetext{
${ }^{69}$ Interviews with Emilia Yanti (GBSBI) on 9 November 2018; Parto Sumarto (KASBI) on 13 November 2018; Elly Silaban (KSBSI/Garteks) on 21 November 2018; Lilis Usman (former SPN, now KSPN) on 23 November 2018; Frank Tan (FSPTSK Reformasi) on 28 November 2018.

${ }^{70}$ Interview with Amalia Falah Alam on 7 November 2018.

${ }^{71}$ Zimmer (2020), pp. 199, 200; Zimmer (2016), p. 5.
} 
International Trade Union Confederation (2019) 2019 ITUC Global Rights Index. The world's worst countries for workers

Lillie N (2004) Global collective bargaining on flag of convenience shipping. Br J Ind Relat 42 (11):47-67

Maquila Solidarity Network (2008) Clearing the hurdles: steps to improving wages and working conditions in the global sportswear industry

Muthmainah (2021) Muthmainah, Muthi, Vereinigungsfreiheit und Gewerkschaftsrechte in Indonesien, Gastbeitrag in: Zimmer, Reingard, Das indonesische Abkommen zum Schutz von Gewerkschaftsrechten (Freedom of Association Protocol). Ein Vorbild für andere internationale Rahmenabkommen? Düsseldorf 2021

Rubya T (2015) The ready-made garment industry: an analysis of Bangladesh's labor law provisions after the Savar tragedy. Brooklyn J Int Law 40(2):684-718

Sobczak A (2012) Ensuring the effective implementation of transnational company agreements. Eur J Ind Relat 18(2):139-151

Stevis D, Fichter M (2012) International Frameworks Agreements in the United States: escaping, projecting, or globalizing social dialogues? Comp Labor Law Policy J 33(4):667-690

Telljohann V, da Costa I, Müller T, Rehfeld U, Zimmer R (2009) International Frame work Agreements: a stepping stone towards the internationalization of industrial relations? European Foundation for the improvement of the working and living condition, Dublin

Ter Haar B, Keune M (2014) One step forward or more window-dressing? A legal analysis of recent CSR initiatives in the garment industry in Bangladesh. Int J Comp Labour Law Ind Relat 30 (1):5-26

Thomas M (2011) Global industrial relations? Framework agreements and the regulation of international labor standards. Labor Stud J 36(2):269-287

Zimmer R (2008) Soziale Mindeststandards und ihre Durchsetzungsmechanismen. Sicherung sozialer Mindeststandards durch Verhaltenskodizes? Nomos, Baden-Baden

Zimmer R (2013a) European works councils as participants in Euro-wide collective agreements analysis from a German perspective. Eur Labour Law J 4(4):312-327

Zimmer R (2013b) Entwicklungsperspektiven transnationaler Kollektivverhandlungen in Europa Schaffung eines rechtlichen Rahmens für transnationale Kollektivverträge in der Europäischen Union. Europäische Zeitschrift für Arbeitsrecht 2:247-259

Zimmer R (2015) EU-Dienstleistungsfreiheit auch für (billig) ausgeflaggte Schiffe. Anmerkung zur EuGH-Entscheidung vom 8. Juli 2014. C-83/13. Arbeit und Recht 3:103-105

Zimmer R (2016) Corporate responsibility in the »Bangladesh Accord«. Which regulations are transferable to other supply chains? Expertise on behalf of the Friedrich-Ebert-Foundation. http://library.fes.de/pdf-files/id-moe/13072.pdf. Accessed Dec 2016

Zimmer R (2020) International Framework Agreements: new developments through better implementation on the basis of an analysis of the Bangladesh Accord and the Indonesian Freedom of Association Protocol. Int Organ Law Rev 17:178-205

Reingard Zimmer is professor of German, European and international labour law at the Berlin School of Economics and Law, Germany. Besides classical labour law courses, she teaches in the program Labour Policy and Globalisation in the German branch of the Global Labour University. She is specialised on collective labour law and transnational issues around social standards. Besides gender analysis, her main research is the internationalisation of collective bargaining. In 2018-2019, she conducted interviews in Indonesia with actors involved in the drafting and supervision of the Indonesian Freedom of Association Protocol. Zimmer is a member of the jury awarding the Hugo-Sinzheimer prize for extraordinary doctoral research in the field of labour law, and serves as an arbitrator for the German Textile Alliance governed by the Federal German Ministry of Economic Cooperation and Development. 
Open Access This chapter is licensed under the terms of the Creative Commons Attribution 4.0 International License (http://creativecommons.org/licenses/by/4.0/), which permits use, sharing, adaptation, distribution and reproduction in any medium or format, as long as you give appropriate credit to the original author(s) and the source, provide a link to the Creative Commons license and indicate if changes were made.

The images or other third party material in this chapter are included in the chapter's Creative Commons license, unless indicated otherwise in a credit line to the material. If material is not included in the chapter's Creative Commons license and your intended use is not permitted by statutory regulation or exceeds the permitted use, you will need to obtain permission directly from the copyright holder. 